\title{
HUBUNGAN TINGKAT KEPERCAYAAN ANGGOTA DAN FUNGSI KELOMPOK DENGAN EFEKTIVITAS KELOMPOK TANI DI KELURAHAN BAGAN PETE KECAMATAN KOTA BARU KOTA JAMBI
}

\author{
Dewi Susanti ${ }^{1)}, \mathrm{Hj}$. Rosyani ${ }^{2)}$ dan Tri Suratno ${ }^{2)}$ \\ 1) Alumni Program Studi Agribisnis Fakultas Pertanian Universitas Jambi \\ 2) Staf Pengajar Program Studi Agribisnis Fakultas Pertanian Universitas Jambi \\ Email: Susantid16@yahoo.com
}

\begin{abstract}
ABSTRAK
Penelitian bertujuan untuk melihat bagaimana tingkat kepercayaan anggota terhadap kelompok, berjalannya fungsi kelompok dan efektivitas kelompok, serta hubungan antara tingkat kepercayaan anggota dengan efektivitas kelompok tani dan hubungan fungsi kelompok dengan efektivitas kelompok tani.Kepercayaan anggota adalah suatu keadaan dimana petani yang merupakan anggota kelompok tani memiliki kemauan, integritas, motivasi kerjasama, dan kejujuran yang lebih baik untuk memenuhi perannya di dalam kelompok tani.Fungsi kelompok tani dalam penelitian ini berdasarkan Peraturan Menteri Pertanian No.82 tahun 2013 tentanng pedoman penumbuhan dan pengembangan kelompok tani dan gabungan kelompok tani. Dalam Permentan No. 82 tahun 2013 kelompok tani memiliki 3 fungsi, yaitu: a. kelas belajar, b. wahana kerjasama, c. unit produksi. Efektivitas kelompok tani yaitu ukuran keberhasilan dalam melakukan kegiatan sesuai dengan tujuan yang ingin dicapai oleh kelompok. Efektivitas kelompok tani dalam penelitian ini diukur melalui indikator produktivitas kelompok dan kepuasan anggota.Jumlah sampel yang diambil dalam penelitian ini adalah sebanyak 50 responden diperoleh dengan menggunakan rumus Taro Yamane kemudian diambil secara proporsional dari setiap kelompok tani.Analisis data dalam penelitian ini adalah uji korelasi Rank Spearman. Hasil penelitian ini menunjukkan bahwa tingkat kepercayaan anggota, efektivitas kelompok, serta fungsi kelas belajar tinggi.Fungsi wahana kerjasama dan fungsi unit produksi rendah.Terdapat hubungan yang signifikan antara tingkat kepercayaan, fungsi kelas belajar dan fungsi unit produksi dengan kepuasan anggota.Terdapat hubungan yang signifikan antara fungsi wahana kerjasama dan unit produksi dengan produktifitas kelompok.
\end{abstract}

Kata Kunci : Kelompok Tani, Tingkat Kepercayaan, Fungsi Kelompok Tani, Efektivitas

\section{ABSTRACT}

The goals of this research is to determine the trust level of members toward group, how the group function works and the group effectiveness and the relation between the trust of members and the effectiveness of farmer members and the relation between group function and effectiveness of farmer group. The trust of member is a condition where farmers who are members of farmer group have better eagerness, integrity, motivation, cooperation and the honesty to fill up their character in the farming group. The function of farmer group in this research is based on the regulation of agriculture ministry Number 82 year 201 about the orientation of growing and developing toward farmer group and farmer group alliance. In this regulation, farmer group has 3 functions include : a. studying class, b. cooperative mode, c. production unit. The effectiveness of farmer group is the measurement of the success in doing activity appropriate with the purpose that is wanted to be achieved by the group. The effectiveness of farmer group in this research is measured through groupproductivity indicators and the satisfication of members. The numbers of sampling in this research are 50 respondents who are got by using Taro Yamane formula then taken proportionally from each farmer group. Data analysis in this research is Rank Spearman correlation test. The result of this research shows that the trust level of members, effectiveness of farmer members and studying class is high. The functions of cooperative mode and production unit is low. There is significant relation among trust level, function of studying class and function of production unit with satisfication of members. There is also significant among the function of cooperative mode and productive unit with effectiveness of group.

Keywords : Farmer group, trust level, the function of farmer group, effectiveness 


\section{PENDAHULUAN}

Pertanian memiliki peranan yang sangat strategis terutama dalam penyediaan pangan bagi masyarakat, penyerapan tenaga kerja, penyediaan bahan baku industri dan bioenergi. Sektor pertanian ini perlu terus dikembangkan guna pemanfaatan potensi pertanian di Indonesia secara baik. Pengembangan sektor pertanian ini erat kaitannya dengan pemberdayaan pelaku utamanya yakni petani. Dalam Peraturan Menteri Pertanian No 82 tahun 2013 disebutkan bahwa pemberdayaan petani ini dilakukan melalui kegiatan pelatihan dan penyuluhan dengan pendekatan kelompok, yaitu dilakukan dengan mengembangkan kelembagaan ditingkat petani. Semakin berkembangnya kelembagaan petani ini yang dikenal sebagai kelompok tani dan gabungan kelompok tani diharapkan mampu menarik petani lebih banyak lagi untuk bergabung. Menurut Mosher dalam Hermanto dan Swastika (2011) menyatakan bahwa syarat pelancar pembangunan pertanian adalah petani yang tergabung di dalam kelompok tani.

Kelompok tani dibentuk berdasarkan surat keputusan, kemudian melalui kelompok tani dimaksudkan menjadi sarana bagi komunikasi antar petani, serta petani dengan kelembagaan lain terkait proses alih teknologi (Wahyuni, 2003). Berdasarkan Peraturan Menteri Pertanian No 82 tahun 2013 tentang pedoman penumbuhan dan pengembangan kelompok tani dan gabungan kelompok tani, kelompok tani memiliki tiga fungsi yaitu : a. fungsi kelas belajar. b. fungsi wahana kerjasama. c. fungsi unit produksi. Berjalannya fungsi ini dengan baik akan memberi dorongan pada petani untuk merasakan manfaat dari keberadaan kelompok tani bagi kelangsungan usahatani mereka dan juga bagi peningkatan kesejahteraan hidup keluarga petani itu sendiri. Sehingga, semakin banyak petani yang akan bergabung dengan kelompok tani. Fungsi kelompok tani merupakan salah satu factor yang mempengaruhi efektivitas kelompok.

Berdasarkan data dari Badan Koordinasi Penyuluhan (BAKORLUH) Provinsi Jambi tahun 2013, kelompok tani yang ada di Provinsi Jambi mencapai 10.098 kelompok.Kota jambi memiliki kelompok tani dengan jumlah 136 kelompok tani. Kota Jambi memiliki 6 kecamatan yaitu Kecamatan Jambi Selatan dengan total jumlah 26 kelompok tani; Kecamatan Telanai Pura dengan total jumlah 24 kelompok tani; Kecamatan Jambi Timur dengan total jumlah 18 kelompok tani; kecamatan Danau Teluk dengan total jumlah 24 kelompok tani; Kecamatan Kota Baru dengan total jumlah kelompok tani terbanyak yaitu sebanyak 38 kelompok; dan Kecamatan Pelayangan dengan total jumlah 12 kelompok tani. Kota Baru sesuai dengan data hasil kompilasi dan validasi penilaian kemampuan kelompok tani tingkat Kota Jambi dari total 38 kelompok tani 17 diantaranya berada pada kelas kemampuan pemula dan 16 diantaranya berada pada kelas kemampuan lanjut.

Kelurahan bagan pete memiliki kelompok tani lebih banyak dibandingkan dengan kelurahan lainnya yang ada di Kecamatan Kota Baru. Berjalannya kelompok tani ini menemui banyak persoalan seperti anggota yang kurang bahkan tidak aktif, kecemburuan sosial diantara anggota kelompok, kurang meratanya bantuan yang didapat masing-masing anggota kelompok, dan petani yang tidak diizinkan bergabung. Menurut Purwanto dkk (2007) dalam Nasrul (2012) permasalahan pada kelembagaan petani ini terletak pada dasar pembentukannya yang berorientasi bukan pada modal sosial. Menurut Fukuyama (2007) modal sosial merupakan nilai dan norma yang dimiliki bersama oleh anggota suatu kelompok masyarakat sehingga memungkinkan terjadinya kerjasama dalam kelompok tersebut. Modal sosial memiliki tiga unsur yaitu kepercayaan, norma, dan jaringan. Kepercayaan merupakan salah satu unsur utama modal sosial yang mampu meningkatkan efektivitas kerjasama suatu kelompok. Kepercayaan yang kuat pada anggota suatu kelompok akan menjadikan anggota kelompok mendahulukan kepentingan bersama kelompoknya (Fukuyama, 2007).

Penelitian ini bertujuan untuk melihat bagaimana tingkat kepercayaan anggota terhadap kelompok, berjalannya fungsi kelompok dan efektivitas kelompok, serta hubungan antara tingkat kepercayaan anggota dengan efektivitas kelompok tani dan hubungan fungsi kelompok dengan efektivitas kelompok tani. 


\section{METODE PENELITIAN}

Ruang lingkup penelitian ini adalah untuk mengetahui tingkat kepercayaan anggota kelompok tani terhadap kelompok tani, berjalannya fungsi kelompok tani dan efektivitas kelompok tani, serta hubungan antara tingkat kepercayaan anggota kelompok tani dengan efektivitas kelompok tani dan hubungan fungsi kelompok tani dengan efektivitas kelompok tani. selanjutnya pemilihan Kelurahan Bagan Pete menjadi tempat penelitian ini dikarenakan Kelurahan Bagan Pete memiliki kelompok tani terbanyak dari semua kelurahan yang ada di kecamatan Kota Baru. Penelitian ini dilaksanakan dari tanggal 27 Juli 2015 sampai 28 September 2015.

Data yang digunakan dalam penelitian ini merupakan data primer yang diperoleh dari wawancara langsung dengan semua petani responden berdasarkan daftar pertanyaan (kuesioner) yang telah disiapkan sebelumnya. Data sekunder diperoleh dari berbagai literatur, laporan penelitian, serta laporan dari dinas atau instansi yang berhubungan dengan penelitian ini. Jumlah sampel yang diambil dalam penelitian ini adalah sebanyak 50 responden yang didapat dengan menggunakan rumus Taro Yamane (Riduan dan Akdon, 2009). 50 responden kemudian diambil secara proporsional dari setiap kelompok tani.

Wawancara dilakukan kepada responden dengan berdasarkan kuisioner yang telah disusun. Analisis yang digunakan dalam penelitian ini adalah analisis statistik deskriftif. Uji hubungan antar variabel digunakan uji korelasi Rank Spearman yang akan dibantu dengan aplikasi Window Exel 2010, kemudian dilanjutkan analisis menggunakan program SPSS (Statistical Product and Service Solutions) versi 20.0 .

Dasar pengambilan keputusan dalam uji korelasi rank spearman ini adalah sebagai berikut :

1. Jika nilai $\alpha$ atau nilai signifakansi $<0.05$ maka dapat disimpulkan bahwa terdapat korelasi yang signifikan antara variabel yang dihubungkan.

2. Jika nilai $\alpha$ atau nilai signifakansi $>0.05$ maka dapat disimpulkan bahwa tidak terdapat korelasi yang signifikan antara variabel yang dihubungkan.

Sedangkan penafsiran untuk tingkat hubungan koefisien korelasi $r_{s}$ antar variabel dilakukan dengan dasar sebagai berikut:

1. $0.00-0.20=$ Hampir tidak ada korelasi

2. $0.21-0.40=$ Korelasi rendah

3. $0.41-0.60=$ Korelasi sedang

4. $0.61-0.80=$ Korelasi tinggi

5. $0.80-1.00=$ Korelasi sempurna

HASIL DAN PEMBAHASAN

\section{Gambaran Kelompok Tani}

Kelurahan bagan pete memiliki jumlah kelompok tani sebanyak 8 kelompok tani berdasarkan data yang diperoleh dari Balai Penyuluhan Pertanian Peternakan Perikanan dan Kehutanan (BP3K) Kota Baru tahun 2014. Kelompok tani yang ada dikelurahan bagan pete ini mengelola komoditi yang beragam seperti hortikultura, peternakan, dan pengolahan hasil. Kelompok tani yang ada sudah mulai berdiri pada tahun 2006.

Anggota kelompok tani kebanyakan mengolah lahan bukan milik sendiri. Lahan yang mereka kelola adalah dengan perjanjian bahwa lahan tersebut akan dibersihkan dan pemilik tidak menerima bagi hasil dari petani penggarap. Kebanyakan kelompok tani belum mendapatkan bantuan yang memadai dari pemerintah. Kelompok tani mendapatkan bantuan bibit dan pupuk. Pupuk bantuan adalah pupuk subsidi, jadi petani anggota kelompok tani masih harus membayar dengan harga yang cukup tinggi untuk mendapatkan pupuk. Bibit yang menjadi bantuan pemerintah juga belum sesuai jumlah kebutuhan petani. Kekurangan pupuk dan bibit untuk keperluan usahatani mereka diatasi 
dengan membeli pupuk dari toko-toko pertanian terdekat. Selain bibit dan pupuk, bantuan yang didapatkan juga berupa ALSINTAN seperti hand traktor, mesin air dan selang, mulsa, dan motor gerobak. Sama halnya dengan bantuan saprodi, bantuan alsintan ini masih jauh dari cukup. Seperti hand traktor baru satu kelompok tani yang mendapatkannya dan jumlahnya satu.

Pemasaran hasil produksi dan modal anggota kelompok tani ini masih mengandalkan tengkulak. Bantuan dana dari pemerintah belum bisa dirasakan oleh anggota kelompok tani. Dana dari pemerintah diberikan sebagai pinjaman dan dari hasil panen dana harus dikembalikan secara utuh meskipun panen tidak berhasil. Hal ini dirasa berat oleh anggota kelompok tani sehingga mereka lebih suka meminjam modal kepada tengkulak. Kelompok tani belum bisa secara kolektif memfasilitasi modal anggotanya. Pengolahan hasil untuk menambah nilai dari hasil produksi belum dilakukan oleh kelompok tani. Satu-satunya kelompok tani pengolahan hasil yang ada di Kelurahan Bagan Pete adalah kelompok wanita tani Stinkin.

\section{Tingkat Kepercayaan Anggota Kelompok terhadap Kelompok Tani}

Penelitian ini membatasi tingkat kepercayaan anggota sebagai suatu keadaan dimana petani yang merupakan anggota kelompok tani memiliki kemauan, motivasi kerjasama, dan kejujuran yang lebih baik untuk memenuhi perannya di dalam kelompok tani (Fukuyama, 2007). Berdasarkan hasil penelitian tingkat kepercayaan anggota kelompok tani di daerah penelitian adalah sebagai berikut.

Tabel 1. Tingkat Kepercayaan Anggota Terhadap Kelompok Tani di Kelurahan Bagan Pete Kecamatan Kota Baru

\begin{tabular}{ccc}
\hline Tigkat Kepercayaan Anggota & $\begin{array}{c}\text { Frekuensi } \\
\text { (Orang) }\end{array}$ & Persentase (\%) \\
\hline Tinggi & 32 & 64 \\
Rendah & 18 & 36 \\
\hline Jumlah & 50 & 100 \\
\hline
\end{tabular}

Tingkat kepercayaan anggota terhadap kelompok tani di daerah penelitian tergolong tinggi seperti terlihat pada Tabel 1, yaitu dengan persentase $64 \%$ atau 32 orang responden. Kerjasama yang terjalin diantara semua komponen kelompok tani dirasakan membaik dengan seiring berkembangnya kelompok tani. Hubungan antara pengurus maupun anggota juga terjalin dengan baik, pengurus dianggap mampu menyelesaikan permasalahan yang ada di dalam kelompok tani dengan baik, meskipun diperlukan waktu untuk menyelesaikan permasalan dan terkadang ada anggota yang merasa tidak puas dengan keputusan yang dihasilkan. Pengurus selalu berbagi Setiap informasi yang ada kepada anggota, terutama informasi dari PPL maupun informasi lain yang berhubungan dengan kelompok tani mereka. Pengurus berusaha dengan baik agar apa yang diputuskan dalam musyawarah kelompok tani dapat dijalankan. Dalam menjalankan tugasnya sebagai pengurus kelompok tani mengedepankan kepentingan anggota dan kelompok tani menjadi tugas penting pengurus. Kenyataanya pengurus melakukan tugas mereka dengan sebaik mungkin dan anggota juga mendukung setiap kegiatan kelompok tani yang diputuskan secara bersama. Musyawarah rutin setiap bulannya yang diadakan kelompok tani mulai berjalan dengan baik tentunya dengan dukungan dari pihak-pihak yang terkait seperti PPL dan instansi lainnya.

\section{Fungsi Kelompok Tani di Kelurahan Bagan Pete Kecamatan Kota Baru}

Fungsi kelompok tani dalam penelitian ini berdasarkan Peraturan Menteri Pertanian No.82 tahun 2013 tentanng pedoman penumbuhan dan pengembangan kelompok tani dan gabungan kelompok tani. Dalam Permentan No. 82 tahun 2013 kelompok tani memiliki 3 fungsi, yaitu: a. kelas 
belajar, b. wahana kerjasama, c. unit produksi. Fungsi kelompok tani ini dirumuskan untuk mengembangkan kelompok tani.Hasil penelitian di daerah penelitian menunjukkan bahwa fungsi kelompok tani berada pada kelas yang seimbang antara kategori yang tinggi dan rendah yaitu 50\%.Berikut ini menunjukkan hasil selengkapnya fungsi kelompok tani di daerah penelitian.

Tabel 2. Fungsi Kelompok Tani di Kelurahan Bagan Pete Kecamatan Kota Baru

\begin{tabular}{ccc}
\hline Fungsi Kelompok Tani & $\begin{array}{c}\text { Frekuensi } \\
\text { (Orang) }\end{array}$ & Persentase (\%) \\
\hline Tinggi & 25 & 50 \\
Rendah & 25 & 50 \\
\hline Jumlah & 50 & 100 \\
\hline
\end{tabular}

Fungsi kelompok tani di daerah penelitian belum berjalan dengan optimal. Fungsi kelas belajar sudah berjalan baik dengan persentase $52 \%$, sedangkan fungsi wahana kerjasama dan fungsi unit produksi masih kurang dengan berada pada kategori rendah. Selengkapnya Dapat dilihat pada tabel berikut ini.

Tabel 3. Tiga Fungsi Kelompok Tani di Kelurahan Bagan Pete Kecamatan Kota Baru

\begin{tabular}{ccccccc}
\hline \multirow{2}{*}{ Kategori } & \multicolumn{6}{c}{ Fungsi Kelompok Tani } \\
\cline { 2 - 7 } & \multicolumn{2}{c}{ a. Kelas Belajar } & b. Wahana Kerjasama & \multicolumn{2}{c}{ c. Unit Produksi } \\
\cline { 2 - 7 } & $\begin{array}{c}\text { Frekuensi } \\
\text { (Orang) }\end{array}$ & $\begin{array}{c}\text { Persentase } \\
(\%)\end{array}$ & $\begin{array}{c}\text { Frekuensi } \\
\text { (Orang) }\end{array}$ & $\begin{array}{c}\text { Persentase } \\
(\%)\end{array}$ & $\begin{array}{c}\text { Frekuensi } \\
\text { (Orang) }\end{array}$ & $\begin{array}{c}\text { Persentase } \\
(\%)\end{array}$ \\
\hline Tinggi & 26 & 52 & 17 & 34 & 24 & 48 \\
Rendah & 24 & 48 & 33 & 66 & 26 & 52 \\
\hline Jumlah & 50 & 100 & 50 & 100 & 50 & 100 \\
\hline
\end{tabular}

\section{Fungsi Kelas Belajar}

Terlihat pada Tabel 3 bahwa fungsi kelas belajar berada pada kategori tinggi yaitu sebesar 52 $\%$ atau 26 orang. Fungsi kelas belajar ini menjadikan kelompok tani sebagai wadah untuk petani meningkatkan pengetahuan, keterampilan dan sikap agar mampu mandiri dan meningkatkan taraf kehidupannya.Kelas belajar dilihat dari pertemuan rurin kelompok, pelatihan yang didapatkan oleh anggota serta anggota kelompok dan pengurus kelompok yang berbagi pengalaman dan wawasan. Instansi terkait juga memberikan kontribusi dalam hal peningkatan pengetahuan petani ini. Anggota kelompok mandapatkan pelatihan yang difasilitasi oleh berbagai instansi pemerintah. Dari kelompok tani sendiri selain pertemuan rutin setiap bulannya juga mendapatkan kunjungan dari PPL maupun instansi lain. dalam pertemuan rutin anggota biasanya membicarakan rencana kelompok tani dan evaluasi program-program yang berjalan. Hal ini juga dimanfaatkan bagi semua anggota yang hadir untuk saling berbagi pengalaman dan pengetahuan mereka dalam proses produksi.

Fungsi kelas belajar ini memberikan tambahan ilmu pengetahuan bagi anggota kelompok tani, namun belum bisa meningkatkan sikap petani agar mau menerapkan apa yang telah didapatkan selama pelatihan. Petani masih berada pada kondisi nyaman untuk tetap bertahan dengan kondisi mereka sekarang yang masih tergantung dengan pihak lain seperti tengkulak. Petani anggota belum bisa mandiri untuk mengelola usahatani mereka dengan lebih baik dan lebih berdaya saing.

\section{Fungsi Wahana Kerjasama}

Tabel 3 menunjukkan bahwa fungsi wahana kerjasama di daerah penelitian berada pada kategori rendah yaitu $66 \%$ atau 33 orang. Untuk fungsi wahana kerjasama ini anggota kelompok tani diharapkan memperkuat kerjasama baik antar anggota sendiri maupun dengan pihak lain. fungsi 
wahana kerjasama dilihat dari kerjasama antar anggota, anggota dan pengurus, juga keterlibatan pihak lain yang menjalin kerjasama dengan kelompok tani.

Dalam kelompok tani diharapkan hubungan baik yang terjalin antara semua anggota kelompok dan pengurus akan melahirkan kerjasama yang baik pula. Dari hasil identifikasi wawancara denga petani responden meskipun hubungan terjalin dengan baik antara semua komponen kelompok tani, namun kerjasama yang ada belum dirasakan oleh anggota. Kerjasama yang ada sebatas kegiatan kelompok rutin seperti musyawarah kelompok.Kegiatan gotong royong yang biasanya dilakukan sebagai salah satu wujud dari hubungan kerjasama yang baik tidak berjalan. Kegiatan gotong royong dilakukan hanya sesekali saja untuk mempersiapkan kegiatan tertentu, seperti persiapan lahan untuk kunjungan dari pejabat instansi pertanian.Kelompok tani didaerah penelitian masih menitikberatkan pada bantuan pemerintah yang ada untuk kelompok tani. Bantuan ini yang kemudian dijadikan andalan dalam pengembangan kelompok tani mereka. Kemandirian masih belum bisa dikembangkan oleh kelompok tani yang ada. Kelompok tani masih belum dapat menjalankan fungsi wahana kerjasama secara optimal.

\section{Fungsi Unit Produksi}

Fungsi unit produksi sesuai dengan Tabel 3 berada pada kategori rendah yaitu $52 \%$ atau 26 orang. Unit produksi dilihat dari kesinambungan produksi yang dijaga secara bersama-sama bagi setiap anggota kelompok tani. Pengembangan usahatani dengan pengelolaan hasil produksi juga penting serta bagaimana kelompok tani berperan untuk mengelola keteraturan pembukuan sebagai referensi keputusan kedepannya. Anggota kelompok tani menjalankan usahatani masing-masing mulai dari sebelum bergabung dikelompok tani. Sejauh yang telah berjalan, kelompok tani yang ada merencanakan kegiatan produksi secara bersama hanya untuk menjalankan program bantuan dari pemerintah. Selain program bantuan pemerintah, semua kegiatan produksi dilakukan secara individu tanpa ada kaitan dengan kelompok tani. Kegiatan produksi dan pengolahan hasil produksi dilakukan secara individu. Kelompok tani belum memfasilitasi adanya pengolahan hasil produksi atau setidaknya pemasaran hasil produksi dari anggota kelompok tani.

\section{Efektivitas Kelompok Tani di Kelurahan Bagan Pete Kecamatan Kota Baru}

Efektivitas kelompok tani yaitu ukuran keberhasilan dalam melakukan kegiatan sesuai dengan tujuan yang ingin dicapai oleh kelompok. Efektivitas kelompok tani dalam penelitian ini diukur melalui indikator produktivitas kelompok dan kepuasan anggota. Hasil penelitian dari petani responden menunjukkan bahwa efektivitas kelompok tani di daerah penelitian termasuk dalam kategori tinggi dengan persentase $52 \%$ atau sebanyak 26 orang. Lebih jelasnya dapat dilihat pada tabel berikut ini.

Tabel 4. Efektivitas Kelompok Tani di Kelurahan Bagan Pete Kecamatan Kota Baru

\begin{tabular}{ccc}
\hline Efektivitas Kelompok Tani & $\begin{array}{c}\text { Frekuensi } \\
\text { (Orang) }\end{array}$ & Persentase (\%) \\
\hline Tinggi & 26 & 52 \\
Rendah & 24 & 48 \\
\hline Jumlah & $\mathbf{5 0}$ & $\mathbf{1 0 0}$ \\
\hline
\end{tabular}

Kelompok tani menampung semua tujuan dari anggotanya kemudian menjadikan tujuan untuk memajukan usahatani setiap anggota kelompok sebagai tujuan utama. Bergabung di kelompok tani ini dirasakan memang semakin memajukan usahatani anggota. Namun tidak semua anggota merasa puas dengan hasil yang sudah dicapai. Meskipun mengakui bahwa keikutsertaannya dalam kelompok tani dan dengan kondisi kelompok tani yang ada sekarang memang berdampak pada lebih 
meningkatnya usahatani yang dilakukan oleh petani anggota. Lebih jelasnya hasil penelitian mengenai indikator efektivitas kelompok tani di desa penelitian dapat dilihat pada tabel berikut ini.

Tabel 5. Indikator Efektivitas Kelompok Tani di Kelurahan Bagan Pete Kecamatan Kota Baru

\begin{tabular}{ccccc}
\hline & \multicolumn{4}{c}{ Efektivitas Kelompok Tani } \\
\cline { 2 - 5 } Kategori & \multicolumn{2}{c}{ a. Produktivitas Kelompok } & \multicolumn{2}{c}{ b. Kepuasan Anggota } \\
\cline { 2 - 5 } & $\begin{array}{c}\text { Frekuensi } \\
\text { (Orang) }\end{array}$ & $\begin{array}{c}\text { Persentase } \\
(\%)\end{array}$ & $\begin{array}{c}\text { Frekuensi } \\
\text { (Orang) }\end{array}$ & $\begin{array}{c}\text { Persentase } \\
(\%)\end{array}$ \\
\hline Tinggi & 27 & 54 & 26 & 52 \\
Rendah & 23 & 46 & 24 & 48 \\
\hline Jumlah & $\mathbf{5 0}$ & $\mathbf{1 0 0}$ & $\mathbf{5 0}$ & $\mathbf{1 0 0}$ \\
\hline
\end{tabular}

\section{Produktivitas Kelompok}

Tabel 5 menunjukkan bahwa efektivitas kelompok tani melalui produktivitas kelompok berada dalam kategori tinggi yaitu dengan jumlah sebanyak 27 orang atau $54 \%$. Hasil ini menunjukkan bahwa produktivitas kelompok tani di daerah penelitian sudah baik. Produktivitas kelompok dapat dilihat dari hasil produksi anggota dan juga hasil produksi kelompok itu sendiri. Dari jawaban responden berdasarkan kuisioner petani anggota kelompok merasakan produktivitas mereka meningkat karena bergabung dengan kelompok tani. Meskipun beberapa kelompok tani tidak memiliki usaha yang dikelola khusus untuk kelompok, usahatani yang dilakukan merupakan usahatani individu anggota kelompok namun produktivitas kelompok tetap meningkat seiring peningkatan produktivitas anggota.

Produktivitas kelompok juga dapat dilihat dari terpenuhinya sarana produksi. Dalam hal ini kelompok tani yang ada masih mengandalkan bantuan dari pemerintah untuk pemenuhan sarana produksi bagi anggota kelompok. Belum ada kelompok tani yang benar-benar mengembangkan kelompok taninya agar secara mandiri mampu memenuhi kebutuhan sarana produksi bagi anggotanya. Dari keterangan petani responden berdasarkan kuisioner mereka sangat mengakui bahwa dengan bergabung dikelompok tani ini pengetahuan mereka tentang pertanian meningkat. Informasi yang didapatkan juga banyak dan lebih cepat. Mulai dari perkembangan pertanian kekinian sampai pada teknologi yang terbaru. Tidak semua teknologi maupun informasi yang didapatkan oleh anggota mereka realisasikan secara langsung pada usahatani mereka. Khususnya informasi mengenai pengolahan hasil, selain dari kelompok tani pengolahan hasil kelompok tani yang lain belum melakukan pengolahan hasil. Semangat awal bagi para anggota kelompok tetap bergabung dengan kelompok tani adalah adanya bantuan pemerintah. Pada akhirnya anggota mulai menyadari bahwa kelompok tani memang mereka butuhkan untuk mengembangkan usahataninya.

\section{Kepuasan Anggota}

Pada Tabel 5 dapat terlihat bahwa kepuasan anggota kelompok tani terhadap kelompok tani tinggi yakni dengan jumlah 26 orang atau $52 \%$. Kepuasan anggota dilihat dengan perasaan anggota yang benar-benar merasa bagian dari kelompok tani dan kebanggaan anggota menjadi bagian dari kelompok tani. Dari hasil penelitian ini melalui keisioner dapat dilihat bahwa responden benar-benar merasa bagian dari kelompok tani dikarenakan pengelolaan kelompok tani yang sudah cukup baik. Anggota kelompok juga merasa sangat bangga menjadi bagian kelompok tani dibandingkan mereka yang tidak tergabung dikelompok tani. Bergabung dikelompok tani merupakan kegiatan yang berguna untuk mencari informasi, juga lebih mudah untuk mendapatkan bantuan dari pemerintah. Kepuasan anggota juga dilihat dari peran anggota dalam kelompok tani serta keterlibatan anggota baik dalam perencanaan maupun pelaksanaan program. Dari hasil kuisioner yang terkumpul responden merasa telah berperan aktif di dalam kelompok taninya. Anggota juga dilibatkan dalam 
perencanaan maupun pelaksanaan program meskipun belum benar-benar sesuai dengan harapan anggota.

Peraturan kelompok tani merupakan salah satu penilaian untuk kepuasan anggota. Dalam hal ini hasil yang didapatkan dari responden menggambarkan bahwa anggota kelompok puas dengan peraturan yang disepakati bersama. Setiap peraturan merupakan hasil musyawarah mufakat bersama semua anggota kelompok, sehingga anggota merasa aspirasi mereka didengarkan oleh pengurus kelompok tani. Perkembangan kelompok tani juga merupakan hal yang penting dalam penilaian kepuasan anggota. Perkembangan kelompok tani yang dirasakan oleh anggota kelompok menjadikan anggota kelompok tani semakin puas terhadap kinerja kelompok tani yang diikuti. Meskipun tidak terlalu cepat namun anggota merasa kelompok tani perlahan-lahan semakin baik kondisi pengelolaannya, anggota merasa ini menunjukkan bahwa kelompok tani mengalami perkembangan yang baik.

\section{Hubungan Tingkat Kepercayaan Anggota dengan Efektivitas Kelompok Tani di Kelurahan Bagan Pete Kecamatan Kota Baru}

Hasil uji rank spearman pada hubungan antara tingkat kepercayaan anggota kelompok dengan efektivitas kelompok tani adalah sebagai berikut:

Tabel 6. Nilai Korelasi Tingkat Kepercayaan dengan Efektivitas Kelompok Tani di Kelurahan Bagan Pete Kecamatan Kota Baru

\begin{tabular}{|c|c|c|c|c|}
\hline \multirow{3}{*}{ Variabel } & \multicolumn{4}{|c|}{ Efektivitas Kelompok } \\
\hline & \multicolumn{2}{|c|}{ Produktivitas Kelompok } & \multicolumn{2}{|c|}{ Kepuasan Anggota } \\
\hline & $r_{s}$ & A & $r_{s}$ & $\alpha$ \\
\hline Tigkat Kepercayaan Anggota & 0.042 & 0.770 & $0.617^{* *}$ & 0.000 \\
\hline
\end{tabular}

Keterangan: ${ }^{* *}$ ) nyata pada $\alpha=0.01$

Hasil uji rank spearman menunjukkan bahwa tingkat kepercayaan anggota kelompok tani terhadap kelompok tani dengan produktivitas kelompok tidak signifikan, namun menunjukkan hubungan yang signifikan dengan kepuasan anggota pada tingkat kepercayaan $99 \%$.

\section{Hubungan antara tingkat kepercayaan anggota dengan produktivitas kelompok}

Berdasarkan Tabel 6 dapat dilihat bahwa hasil uji kerelasi menunjukkan tidak terdapat hubungan yang signifikan antara tingkat kepercayaan anggota dengan produktivitas kelompok. Nilai signifikansi $(\alpha)$ antar variabel ini sebesar $0.770>0.05$ yang menandakan tidak ada hubungan yang signifikan seperti yang telah dijelaskan sebelumnya. Hasil perhitungan nilai derajat hubungan $\left(r_{s}\right)$ sebesar 0.042. Hal ini berarti derajat hubungan antara tingkat kepercayaan anggota dengan produktivitas kelompok adalah sebesar $4.2 \%$. Hampir tidak terdapat korelasi yang nyata antara tingkat kepercayaan anggota dengan produktivitas kelompok pada tingkat kepercayaan $99 \%$. Hal ini menunjukkan bahwa sebesar apapun rasa percaya yang dimiliki anggota terhadap kelompok tani tidak akan menaikkan produktivitas kelompok secara signifikan di daerah penelitian. Dari hasil analisis kuisioner diketahui rata-rata responden masih belum merasakan kenaikan produktivitas pada produksi usahataninya.Begitu juga kenaikan pendapatan yang masih belum dirasakan oleh rata-rata dari anggota kelompok. Anggota percaya kepada kelompok tani lebih karena kondisi pengelolaan kelompok tani yang semakin membaik.

Hasil penelitian ini berbeda dengan hasil penelitian Lenggono, (2004) tentang modal sosial dalam pengelolaan tambak yang menunjukkan bahwa para petambak yang sangat kecewa sehingga 
tidak percaya terhadap anggota masyarakat ataupun keluarga yang terlibat dalam kegiatan pengaturan pasokan air, ternyata mendapatkan nilai tambah peningkatan produktivitas yang lebih besar dibandingkan dengan yang lainnya.

Kepercayaan seperti pendapat Fukuyama (2007) seharusnya mendorong anggota kelompok untuk bekerjasama dan melakukan tindakan yang lebih efektif. Dalam hal ini kelompok tani belum mampu menjadi saran mengkoordinasikan anggota kelompoknya untuk bisa melakukan tindakan yang lebih efektif bagi kemajuan usahataninya. Contohnya seperti belum sepenuhnya anggota kelompok tani menerapkan apa yang telah mereka dapatkan dari kegiatan kelompok tani. Salah satu contohnya pelatihan pembuatan pupuk kompos yang ada dikelompok tani belum mendorong petani untuk membuat pupuk kompos sendiri untuk kebutuhan usahatani mereka.

\section{Hubungan antara tingkat kepercayaan anggota dengan kepuasan anggota}

Hasil analisis uji korelasi rank spearman antara tingkat kepercayaan anggota dengan kepuasan anggota seperti yang disajikan pada tabel 6 memperlihatakan adanya hubungan yang sangat nyata antara tingkat kepercayaan anggota dengan kepuasan anggota. Hasil perhitungan derajat hubungan $\left(r_{s}\right)$ antara tingkat kepercayaan anggota dengan kepuasan anggota adalah sebesar 0.617. Hal ini berarti terdapat derajat hubungan antara tingkat kepercayaan anggota dengan kepuasan anggota sebesar $61.7 \%$. Nilai signifikansi antara tingkat kepercayaan anggota dengan kepuasan anggota sebesar $0.000<0.05$ yang menunjukkan korelasi yang signifikan antara tingkat kepercayaan anggota dengan kepuasan anggota pada tingkat kepercayaan $99 \%$. Penelitian ini bermakna bahwa semakin besar tingkat kepercayaan anggota kelompok tani terhadap kelompok tani akan semakin meningkatkan kepuasan anggota terhadap kelompok tani.

Penelitian ini sejalan dengan hasil penelitian Rahmawati (2011) yang menyatakan dengan adanya kepercayaan pegawai terhadap perusahaan salah satunya dipengaruhi oleh rasa puas terhadap perusahaan tersebut. Keadaan pengelolaan kelompok yang semakin baik menjadikan anggota kelompok memiliki perasaan yang positif terhadap kelompok tani. Belum semua tujuan anggota kelompok tercapai, namun dengan bergabungnya di kelompok tani dan cukup mendapatkan perhatian dari berbagai pihak menjadikan anggota kelompok merasa cukup puas. Aktif di dalam kelompok tani memberikan manfaat lebih bagi anggota kelompok dibandingkan dengan tidak bergabung di dalam kelompok tani. Salah satu manfaat yang dirasakan anggota bergabung dikelompok tani adalah berpartisipasi dalam kegiatan yang diadakan oleh instansi bekerja sama dengan kelompok tani.

\section{Hubungan Fungsi Kelompok Tani dengan Efektivitas Kelompok Tani di Kelurahan Bagan Pete Kecamatan Kota Baru}

Hasil uji rank spearman pada hubungan antara fungsi kelompok tani dengan efektivitas kelompok tani adalah sebagai berikut: 
Tabel 7. Nilai Korelasi Fungsi Kelompok Tani dengan Efektivitas Kelompok Tani

\begin{tabular}{lcccc}
\hline & \multicolumn{4}{c}{ Efektivitas Kelompok } \\
\cline { 2 - 5 } Variabel & \multicolumn{2}{c}{ Produktivitas Kelompok } & \multicolumn{2}{c}{ Kepuasan Anggota } \\
\cline { 2 - 5 } & $\mathrm{r}_{\mathrm{s}}$ & $\alpha$ & $\mathrm{r}_{\mathrm{s}}$ & $\alpha$ \\
\hline Fugsi Kelas Belajar & 0.071 & 0.626 & $0.438^{* *}$ & 0.001 \\
Fungsi Wahana Kerja Sama & $0.454^{* *}$ & 0.001 & -0.074 & 0.608 \\
Fungsi Unit Produksi & $0.624^{* *}$ & 0.000 & $0.483^{* *}$ & 0.000 \\
\hline
\end{tabular}

Keterangan: ${ }^{* *}$ ) nyata pada $\alpha=0.01$

Berdasarkan uji korelasi rank sperman pada tabel 7 menunjukkan dari ketiga fungsi kelompok tani terdapat satu fungsi kelompok tani yang tidak berkorelasi dengan signifikan yaitu fugsi kelas belajar dengan produktifitas kelompok. Dua fungsi lainnya memiliki korelasi yang signifikan dengan produktifitas kelompok.

\section{Hubungan antara Fungsi Kelompok Tani dengan Produktifitas Kelompok Tani}

Hasil perhitungan derajat hubungan $\left(r_{s}\right)$ antara fungsi kelas belajar dengan produktifitas kelompok adalah sebesar 0.071. Nilai signifikansi antar fungsi kelas belajar dengan produktifitas kelompok adalah $0.626>0.05$ yang artinya tidak terdapat korelasi yang sinifikan. Penelitian ini berarti meskipun fungsi kelompok tani sebagai kelas belajar telah berjalan dengan baik, maka produktifitas kelompok di daerah penelitian belum dapat ditingkatkan. Kelompok tani menjalankan fungsi kelas belajar masih mengandalkan program atau kegiatan dari luar kelompok. Kelompok tani belum mampu menjadi wadah bagi anggotanya agar dapat merumuskan kebutuhan belajarnya sendiri. Hal ini sejalan dengan hasil penelitian Yani (2009) yang menyimpulkan bahwa kelompok tani belum mampu memfasilitasi anggotanya dalam fungsi kelas belajar ini.

Hasil perhitungan derajat hubungan $\left(r_{s}\right)$ fungsi wahana kerjasama dengan produktivitas kelompok adalah sebesar 0.454 . Hal ini menunjukkan terdapat derajat hubungan yang nyata antara fungsi wahana kerjasma dengan produktivitas kelompok. Nilai signifikansi antar fungsi wahana kerjasama dengan produktifitas kelompok adalah $0.001<0.05$ yang artinya terdapat korelasi yang sinifikan. Penelitian ini berarti dengan meningkatnya fungsi wahana kerjasama yang ada pada kelompok tani maka akan meningkatkan produktivitas kelompok. Fungsi wahana kerjasama mendorong anggota kelompok untuk menjalin kerjasama dengan berbagai pihak. Kerjasama yang terjalin ini akan memberikan kemudahan pada anggota kelompok untuk mendapatkan dukungan yang menunjang peningkatan usahatani mereka.

Hasil perhitungan derajat hubungan $\left(r_{s}\right)$ antara fungsi unit produksi dengan produktifitas kelompok adalah sebesar 0.624 . Hal ini menunjukkan terdapat derajat hubungan yang nyata antar fungsi unit produksi dengan produktifitas kelompok. Nilai signifikansi antar fungsi unit produksi dengan produktifitas kelompok adalah $0.000<0.05$ yang artinya terdapat korelasi yang sinifikan. Penelitian ini berarti fungsi unit produksi yang terus meningkat akan berdampak pada meningkatnya produktivitas kelompok. Anggota mengungkapkan meningkatnya pengetahuan mengenai usahatani mereka selama bergabung dengan kelompok tani. Peningkatan pengetahuan ini belum dibarengi dengan aplikasi pada usahatani para anggota.

Hasil penelitian ini berbeda dengan hasil penelitian Astuti (2010) yang menunjukkan bahwa semakin baik fungsi yang berjalan dikelompok tani akan semakin meningkatkan efektivitas kelompok tani tersebut. Dalam penelitian ini fungsi kelas belajar berada dalam kategori tinggi namun tidak meningkatkan varibel efektivitas kelompok. 


\section{Hubungan antara Fungsi Kelompok Tani dengan Kepuasan Anggota}

Hasil perhitungan derajat hubungan $\left(r_{s}\right)$ antara fungsi kelas belajar dengan kepuasan anggota adalah sebesar 0.438 . Hal ini menunjukkan terdapat derajat hubungan yang nyata antar fungsi kelas belajar dengan kepuasan anggota. Nilai signifikansi antar fungsi kelas belajar dengan kepuasan anggota adalah 0.001 yang artinya terdapat korelasi yang sinifikan. Penelitian ini berarti dengan meningkatnya fungsi kelas belajar maka akan meningkatkan kepuasan anggota terhadap kelompok tani. Penelitian ini sejalan dengan Permentan No 82 tahun 2013 bahwa kelompok tani harus mampu menjadi wadah bagi para petani untuk terus meningkatkan usahatani yang dilakukan oleh para anggota kelompok tani serta meningkatkan kemandirian petani melalui kelompok tani. Dari fungsi kelas belajar inilah salah satu harapan petani terhadap kelompok tani terpenuhi. Mendapatkan banyak tambahan wawasan dan pengetahuan tentang bidang pertanian yang menurut anggota tidak akan mereka dapatkan jika tidak bergabung dengan kelompok tani.

Hasil perhitungan derajat hubungan $\left(r_{s}\right)$ fungsi wahana kerjasama dengan kepuasan anggota adalah sebesar -0.074 . Artinya fungsi wahana kerjasama berhubungan tidak nyata dengan kepuasan anggota kelompok tani. Nilai signifikansi antar fungsi wahana kerjasama dengan kepuasan anggota adalah $0.608<0.05$ yang artinya tidak terdapat korelasi yang sinifikan. Kerjasama anggota yang belum berjalan dengan baik sehingga anggota kelompok belum merasakan manfaat dari kelompok tani sebagai sarana bagi anggotanya membangun jaringan kerjasama yang menguntungkan dengan berbagai pihak. Belum berjalannya fungsi kerjasama ini juga menunda kelompok tani untuk lebih mandiri. Berbeda dengan hasil penelitian Yani (2009) yang menunjukkan hasil bahwa kelompok tani cukup baik dalam fungsi wahana kerjasama sehingga anggota kelompok dapat menjalin kerjasama dengan penyedia modal yaitu salah satu Bank yang ada.

Hasil perhitungan derajat hubungan $\left(r_{s}\right)$ antara fungsi unit produksi dengan kepuasan anggota adalah sebesar 0.483 . Hal ini menunjukkan terdapat derajat hubungan yang nyata antar fungsi unit produksi dengan kepuasan anggota. Nilai signifikansi antar fungsi unit produksi dengan produktifitas kelompok adalah 0.000 yang artinya terdapat korelasi yang sinifikan. Penelitian ini berarti fungsi unit produksi yang terus meningkat akan berdampak pada meningkatnya kepuasan anggota kelompok tani. Bertambahnya produksi yang dihasilkan oleh petani anggota kelompok tani akan meningkatkan semangat dalam berusahatani. Hasil produksi meningkat pendapatan petani anggota juga akan meningkat. Tercapainya tujuan kelompok tani untuk meningkatkan usahatani anggota juga meningkat. Bagi petani anggota kelompok tani kebutuhan mereka untuk tetap bergabung dengan kelompok tani adalah untuk meningkatkan usahatani mereka baik dalam hal produksi, pendapatan maupun pengetahuan petani.

\section{KESIMPULAN}

Kelompok tani di Kelurahan Bagan Pete memiliki tingkat kepercayaan anggota yang tinggi terhadap kelompok tani.Fungsi kelompok tani masih berjalan belum optimal, Fungsi kelas belajar dinyatakan cukup tinggi oleh responden, fungsi wahana kerjasama dinyatakan masih rendah, dan fungsi produksi juga dinyatakan rendah.Efektivitas kelompok tani dalam ketegori tinggi.Terdapat hubungan yang tidak sigifikan antara tingkat kepercayaan anggota dengan produktivitas kelompok,fungsi kelas belajar dengan produktivitas kelompok. Serta terdapat hubungan yang signifikan antara tingkat kepercayaan anggota dengan kepuasan anggota, fungsi kelas belajar dengan kepuasan anggota, fungsi wahana kerjasama dengan produktivitas kelompok, wahana kerjasama dengan kepuasan anggota, fungsi unit produksi dengan produktivitas kelompok, dan juga fungsi unit produksi dengan kepuasan anggota. 


\section{UCAPAN TERIMA KASIH}

Ucapan terimakasih disampaikan kepada Dekan Fakultas Pertanian Universitas Jambi dan Ketua Program Studi Agribisnis Fakultas Pertanian Universitas Jambi yang telah memfasilitasi pelaksanaan penelitian ini, selain itu penulis juga ingin mengucapkan terimakasih kepada Bapak Lurah beserta jajaran di Kelurahan Bagan Pete, Bapak dan Ibu PPL yang bertugas di Kelurahan Bagan Pete dan semua Anggota Kelompok Tani yang bersedia membantu pelaksanaan penelitian di lapangan.

\section{DAFTAR PUSTAKA}

Astuti. A.N. 2010. Analisis Efektivitas Kelompok Tani di Kecamatan Gatak Kabupaten Sukoharjo. Skripsi Fakultas Pertanian Universitas Sebalas Maret Surakarta. Diunduh dari: repository.uns.ac.id/5606 (diakses 9 oktober 2014)

Badan koordinasi Penyuluhan. 2013. Data Pentuluh Pertanian dan Kelompok Tani Provinsi Jambi. BAKORLUH PROVINSI JAMBI, Jambi.

Balai Penyuluhan Pertanian Perikanan dan Kehutanan.2014. Kompilasi Penilaian Kelas Kemampuan Kelompok Tani Kota Baru Tahun 2014. BP3K Kota Baru, Jambi.

Departemen Pertanian. 2013. Pedoman Pembinaan Kelompok Tani dan Gabungan Kelompok Tani. Kementrian Pertanian. Jakarta

Fukuyama F. 2007. Trust Kebajikan Sosial dan Penciptaan Kemakmuran. Qalam, Yogyakarta

Hermanto dan DKS.Swastika. 2011. Penguatan Kelompok Tani: Langkah Awal Peningkatan Kesejahteraan Petani. J. Analisis Kebijakan Pertanian. Volume 9(4). Pusat Sosial Ekonomi dan Pertanian, Bogor

Lenggono, PS . 2004. Modal Sosial dalam Pengelolaan Tambak (Studi Kasus Pada Komunitas Petambak di Desa Muara Pantuan Kecamatan Anggganan Kabupaten Kutai Kertanegara). Diunduh dari : http://repository.ipb.ac.id (di akses 22 Oktober 2014).

Rahmawati D. 2011. Model Hubungan Sosial OCB (Organizational Citizenship Behavior) dan Kepercayaan di PDAM TIRTA Kahuripan Kabupaten Bogor. Sumber: http://repository.ipb.ac.id di akses pada tanggal 22 Oktober 2014.

Riduwan dan Akdon. 2009. Rumus dan Data dalam Analisis Statistika. Alfabeta, Bandung

Wahyuni. S. 2003. Kinerja Kelompok Tani Dalam Sistem Usahatani Padi dan Metode Pemberdayaaanya. J. Litbang Pertanian, 22(1), 2003. Pusat Penelitian dan Pengembangan Sosial Ekonomi Pertanian. Bogor

Yani, D.E. 2009. Persepsi Anggota terhadap Peran Kelompok Tani Pada Penerapan Teknologi Usahatani Belimbing (Kasus Kelompok Tani Kelurahan Pasir Putih, Kecamatan Sawangan, Kota Depok). Tesis Sekolah Pasca Sarjana Fakultas Ekologi Manusia Institut Pertanian Bogor. Diunduh dari : http://repository.ipb.ac.id (di akses 22 Oktober 2014). 